\title{
Evaluation of morbillivirus exposure in cetaceans from the northern Gulf of Mexico 2010-2014
}

\author{
Deborah A. Fauquier ${ }^{1, *}$, Jenny Litz ${ }^{2}$, Susan Sanchez ${ }^{3}$, Kathleen Colegrove ${ }^{4}$, \\ Lori H. Schwacke ${ }^{5}$, Leslie Hart ${ }^{5,6}$, Jeremiah Saliki ${ }^{3}$, Cynthia Smith ${ }^{7}$, \\ Tracey Goldstein $^{8}$, Sabrina Bowen-Stevens ${ }^{9}$, Wayne McFee ${ }^{5}$, Erin Fougeres ${ }^{10}$, \\ Blair Mase-Guthrie ${ }^{2}$, Elizabeth Stratton ${ }^{9}$, Ruth Ewing ${ }^{2}$, Stephanie Venn-Watson ${ }^{7}$, \\ Ruth H. Carmichael ${ }^{11}$, Connie Clemons-Chevis ${ }^{12}$, Wendy Hatchett ${ }^{12}$, \\ Delphine Shannon ${ }^{12}$, Steve Shippee ${ }^{13,14}$, Suzanne Smith ${ }^{15,16}$, Lydia Staggs ${ }^{16}$, \\ Mandy C. Tumlin ${ }^{17}$, Noel L. Wingers ${ }^{11}$, Teri K. Rowles ${ }^{1}$ \\ ${ }^{1}$ NOAA/National Marine Fisheries Service, Office of Protected Resources, Silver Spring, MD 20910, USA \\ ${ }^{2}$ NOAA/National Marine Fisheries Service, Southeast Fisheries Science Center, Miami, FL 33149, USA \\ ${ }^{3}$ Athens Veterinary Diagnostic Laboratory, College of Veterinary Medicine, University of Georgia, Athens, GA 30602, USA \\ ${ }^{4}$ Zoological Pathology Program, University of Illinois, Maywood, IL 60153, USA \\ ${ }^{5}$ NOAA National Ocean Service, National Center for Coastal Ocean Science, Charleston, SC 29412, USA \\ ${ }^{6}$ College of Charleston, Department of Health and Human Performance, Charleston, SC 29424, USA \\ ${ }^{7}$ National Marine Mammal Foundation, San Diego, CA 92106, USA \\ ${ }^{8}$ One Health Institute, School of Veterinary Medicine, University of California, Davis, CA 95616, USA \\ ${ }^{9}$ NOAA Affiliate, Southeast Fisheries Science Center, Miami, FL 33149, USA \\ ${ }^{10}$ NOAA/National Marine Fisheries Service, Southeast Regional Office, St. Petersburg, FL 33701, USA \\ ${ }^{11}$ Dauphin Island Sea Lab and University of South Alabama, Dauphin Island, AL 36528, USA \\ ${ }^{12}$ Institute for Marine Mammal Studies, Gulfport, MS 39502, USA \\ ${ }^{13}$ Emerald Coast Wildlife Refuge, Fort Walton Beach, FL 32548, USA \\ ${ }^{14}$ Marine Wildlife Response, Mary Esther, FL 32569, USA \\ ${ }^{15}$ Audubon Aquarium of the Americas, New Orleans, LA 70130, USA \\ ${ }^{16}$ GulfWorld Marine Park, Panama City Beach, FL 32413, USA \\ ${ }^{17}$ Louisiana Department of Wildlife and Fisheries, Baton Rouge, LA 70358, USA
}

\begin{abstract}
The potential role of morbillivirus was evaluated in the deaths of $>1100$ bottlenose dolphins Tursiops truncatus and other small cetaceans that stranded from February 2010 through July 2014, during the northern Gulf of Mexico (GoM) unusual mortality event (UME). Morbillivirus analysis was carried out on 142 live or freshly dead cetaceans and results were combined with samples from 102 live, free-ranging bottlenose dolphins sampled during capture-release health assessments conducted from 2011 to 2014. Polymerase chain reaction (PCR) testing for morbillivirus showed that $9.9 \%(14 / 142)$ of the stranded cetaceans and $1 \%(1 / 83)$ of the free-ranging live dolphins were positive for dolphin morbilliviral (DMV) RNA. In contrast, previous DMV dolphin die-offs had DMV detectable by PCR in 61 to $97 \%$ of animals tested. Histologic findings consistent with morbillivirus infection, including lymphoid depletion, bronchointerstitial pneumonia, syncytial cell formation, or meningoencephalitis, were found in $6.6 \%(9 / 136)$ of the cetaceans that underwent histologic examinations. Serological analysis using a virus neutralization assay found that $29 \%(5 / 17)$ of live stranded and $23 \%$ (23/102) of live free-ranging bottlenose dolphins had titers of 64 or greater for cetacean morbillivirus, indicating prior but not necessarily recent exposure to morbillivirus. Current findings suggest that DMV infection, although present in the northern GoM, was sporadic and occurred at low levels and therefore was not the primary cause of the northern GoM UME. Confirmation of DMV infections and existing DMV titers demonstrate continued exposure to morbillivirus among northern GoM cetaceans since the first detection of this virus in the early 1990s.
\end{abstract}

KEY WORDS: Dolphin - Strandings - Tursiops truncatus $\cdot$ Unusual mortality event $\cdot$ Polymerase chain reaction 


\section{INTRODUCTION}

Dolphin morbillivirus (DMV) is a highly contagious paramyxovirus that is well-recognized to cause dolphin die offs in the United States, including those that occurred along the US east coast (in 1987-1988 and 2013-2015) and the Gulf of Mexico (GoM) in 1993-1994 (Lipscomb et al. 1994, 1996, Krafft et al. 1995, Van Bressem et al. 2014). DMV is most closely related to the measles, rinderpest, and peste des petits ruminants viruses (Haffar et al. 1999, Saliki et al. 2002). Five types of morbillivirus have been detected in marine mammals in US waters. Of these, 2 are found in pinnipeds and sea otters: (1) canine distemper virus in seals and (2) phocine distemper virus in sea otters and seals. Those found in cetaceans such as dolphins, porpoises and whales include (3) DMV, (4) porpoise morbillivirus, (5) pilot whale morbillivirus and (6) Longman's beaked whale morbillivirus (Kennedy 1998, Taubenberger et al. 2000, DiGuardo et al. 2005, Van Bressem et al. 2014). Dolphins with morbillivirus infections often die either due to acute viral pneumonia, viral encephalitis, or from fungal or bacterial infections secondary to pan-lymphoid depletion and immunosuppression (Van Bressem et al. 2014). Morbilliviruses are thought to spread through inhalation of respiratory particles or through direct contact between animals, including exposure to the virus through other entryways such as the eyes, mouth, stomach, skin wounds, and the urogenital tract (Van Bressem et al. 2014). When exposed to morbillivirus, animals that survive the initial infection may acquire immunity that is protective against future infections and severe clinical disease (Van Bressem et al. 2009).

Beginning in early 2010 a cetacean unusual mortality event (UME) occurred in the northern GoM involving primarily bottlenose dolphins Tursiops truncatus, with $>1100$ cetaceans stranded during this period (Litz et al. 2014, NOAA Fisheries OPR 2016). Since morbillivirus infection was a common cause of previous dolphin die-offs along the US coast, it was investigated as a potential cause of the northern GoM UME (Litz et al. 2014, Venn-Watson et al. 2015). During previous morbillivirus-associated dolphin die-offs in the USA, the presence of virus detected using polymerase chain reaction (PCR) assays had positive detection rates of 61 and $97 \%$ in dolphins tested during the 1987-1988 and 2013-2015 midAtlantic and 1993-1994 GoM mortality events (Krafft et al. 1995, Lipscomb et al. 1996, Schulman et al. 1997, Fauquier et al. 2014, Litz et al. 2014). Previously reported morbillivirus seropositivity in free-rang- ing and stranded cetacean populations in the GoM during non-UME periods have ranged from 15 to $24 \%$, depending upon the species and stock tested (Duignan et al. 1996, Rowles et al. 2011). To determine the extent of DMV exposure and infections in cetaceans in the northern GoM and to assess the possibility that DMV was contributing to the GoM UME we conducted PCR, histopathologic, and serologic analyses for DMV in live and fresh-dead stranded small cetaceans and in live free-ranging bottlenose dolphins sampled from February 2010 through July 2014.

\section{MATERIALS AND METHODS}

\section{Data and sample collection}

The National Oceanic and Atmospheric Administration's (NOAA) National Marine Fisheries Service (NMFS) Southeast Region Marine Mammal Stranding Network comprises state and non-government organizations in coastal states from Texas through North Carolina, including Puerto Rico and the US Virgin Islands. For each stranding reported to the stranding network in these areas, the responding agencies complete a 'Marine Mammal Stranding Report-Level A Data' form (NOAA Form 89-864 (rev.2007) Office of Management and Budget, OMB, No. 0648-0178). Level A data are available to the public and include species, date, location, body condition, sex, length, etc. 'Stranded' cetaceans included animals that stranded live or dead, and live animals that were sampled during emergency responses. For this study, data and samples were collected from selected cetaceans from the originally declared region of the northern GoM UME, in areas from Franklin County, Florida west to the Louisiana-Texas state line. The stranding data reported here were extracted from the NOAA Marine Mammal Health and Stranding Response National Database and are the most accurate available as of October 15, 2015.

Live stranded animals were evaluated, and post mortem examinations of cetaceans were conducted by network participants either in the field or at institutional facilities for animals that stranded from February 2010 through July 2014. Tissues collected for histopathologic examination were preserved in $10 \%$ neutral buffered formalin using standardized sampling protocols, and additional samples were collected and frozen for pathogen analyses (Geraci \& Lounsbury 1993, Rowles et al. 2001). Cetaceans were separated into age categories based upon age deter- 
mination from growth layer counts of teeth (Hohn et al. 1989) or upon standard length ranges (Read et al. 1993) if teeth were not available. Tissues from stranded cetaceans were collected and stored under chain of custody rules to insure integrity, and were subsequently transferred to NOAA under national resource damage assessment (NRDA) criteria, after which they were sent to designated facilities for analysis (Deepwater Horizon NRDA Trustees 2016). While a standard sampling method was used by contributing institutions, the specific organ systems sampled differed among cases depending upon organ availability, carcass condition, and experience of the prosector.

Tissues from stranded cetaceans including blood, blowhole swab, brain, lymph node(s), lung, spinal cord and spleen were evaluated from DMV infection via PCR analysis. Additionally, serum from live stranded cetaceans was collected for virus neutralization (VN) testing. Tissues from dead animals were selected for DMV testing based upon carcass decomposition code (with samples prioritized from freshly dead and early moderately decomposed carcasses), availability of suitable samples, geographic and temporal distribution, and/or presence of characteristic lesions such as lymphoid depletion, bronchointerstitial pneumonia, syncytial cell formation or meningoencephalitis found during histopathologic evaluation. Consistent with previous dolphin morbillivirus UME investigations, confirmed DMV cases were defined as dolphins exhibiting at least 1 characteristic histopathologic lesion and 1 PCR positive tissue. Suspect cases were dolphins with either characteristic histopathologic lesions or PCR positive tissues; negative cases were those with negative PCR tests and no characteristic histopathologic lesions detected.

Free-ranging bottlenose dolphins were temporarily captured and released on site in Barataria Bay, Louisiana (BB), during August 3-16, 2011, June 17-28, 2013, June 9-20, 2014; and in Mississippi Sound, Mississippi, (MS) during July 23-August 1, 2013 as part of the Deepwater Horizon NRDA as described in Schwacke et al. (2014) and Smith et al. (2017, this Theme Section). Blowhole swabs were collected for PCR analysis, and serum samples were collected for VN testing. Age determination was conducted as described previously for stranded cetaceans.

\section{PCR analysis}

The morbillivirus PCR assay was performed as follows. RNA was extracted from tissues using the
QIAmp cador Pathogen kit (Qiagen), using $0.5 \mathrm{~g}$ of tissue macerate, following the manufacturer's instructions. PCR was carried out by conventional semi-nested reverse transcription PCR, which amplifies a 300 bp product within a conserved region in the phosphoprotein gene (P-gene) (Barrett et al. 1993, Sierra et al. 2014). Partial sequences of the P-gene from the pan-morbillivirus PCR were compared against morbilliviral sequences available in the GenBank database.

Additionally, samples from 3 positive cetaceans were submitted for whole genome sequencing. Primers for whole genome sequencing were designed against the only fully sequenced DMV available (Rima et al. 2005; see Fig. 2) to amplify the entire genome of dolphin morbilliviruses. RNA was extracted from the 3 animals (spinal cord from a bottlenose dolphin from Mississippi in 2011, lung from a bottlenose dolphin from Louisiana in 2011 and lung from a spinner dolphin Stenella longirostris from Florida in 2010) using TRIzol reagent (Invitrogen), and cDNA was transcribed using the Superscript III First Strand kit (Invitrogen). PCR was performed to amplify all segments, bands of correct size were excised and purified PCR products were cloned (pCR4-TOPO vector; Invitrogen) and sequenced (ABI 3730 Capillary Electrophoresis Genetic Analyzer; Applied Biosystems).

Sequences were identified and confirmed using the nucleotide and translated nucleotide BLAST search tools within the National Center for Biotechnology Information (NCBI) database. Plasmid and primer sequences were removed and chromatograms were analyzed for ambiguities using Geneious Pro v9.0.5 software (Biomatters). Nucleotide sequences were aligned, assembled and consensus genome sequences generated. Nucleotide sequences were obtained from the GenBank database for phylogenetic analysis, and alignments were performed using the Muscle alignment tool in Geneious Pro (Biomatters). A neighbor-joining bootstrap tree (1000 replicates, Tamura-Nei model) comparing the corresponding P-gene fragments (389 bp) of known morbilliviruses was produced using PAUP* ${ }^{*} 4.0$ software (Sinauer).

\section{Serological analysis}

Antibody titers against cetacean morbilliviruses were measured using the microtiter VN test (Rossiter et al. 1985), as described by Saliki \& Lehenbauer (2001). Titers were expressed as the reciprocal of the 
Table 1. Fluid and tissues of cetaceans stranded in the Gulf of Mexico in 2010-2014 tested for morbillivirus by polymerase chain reaction (PCR)

\begin{tabular}{|lrrr|}
\hline Tissue type & Total tested & \multicolumn{2}{c|}{ Morbillivirus positive } \\
& & No. & $\%$ \\
\hline Blowhole swab & 1 & 0 & 0 \\
Brain/spinal cord & 101 & 7 & 7 \\
Lung & 132 & 11 & 8 \\
Lymph node(s) & 26 & 4 & 15 \\
Spleen & 20 & 3 & 15 \\
Whole blood & 9 & 0 & 0 \\
Total & 289 & 25 & 9 \\
\hline
\end{tabular}

highest dilution of serum that completely neutralized cytopathic effects in duplicate wells. Titers $\leq 8$ were considered to be seronegative while titers $\geq 64$ were considered to be seropositive for this study. Titers between 16 and 32 were considered to be equivocal to reduce the likelihood of false positives as described in Van Bressem et al. (2014).

\section{RESULTS}

\section{PCR results}

Between February 2010 and July 2014, samples from 128 stranded bottlenose dolphins and 14 other stranded small cetaceans from the northern GoM were tested for morbilliviral RNA by PCR with a total of 289 tissue samples used in the analysis (Tables 1 \& 2). Of the 142 animals, $9.9 \%(14 / 142)$ had detectable morbilliviral RNA in at least 1 tissue including brain, lung, lymph node, spinal cord and spleen (Table 1). Eight animals were PCR positive in only 1 tissue, 3 were positive in 2 tissues, and 3 were positive in 3 or more tissues. Of the 14 positive cetaceans, 12 were bottlenose dolphins, one was a Clymene dolphin Stenella clymene and one was a spinner dolphin (Table 2).

Stranded dolphins were tested from northwestern Florida, Alabama, Mississippi and Louisiana and at least 1 cetacean tested positive for morbillivirus via PCR in each of the 4 states. Bottlenose dolphins were tested from all 4 states. Additionally, Atlantic spotted dolphins Stenella frontalis were tested in Alabama and Florida; and the Clymene dolphin, melonheaded whales Peponocephala elec-
Table 2. Cetacean species stranded in the Gulf of Mexico in 2010-2014 tested for morbillivirus by PCR

\begin{tabular}{|lrrr|}
\hline \multirow{2}{*}{ Common name } & $\begin{array}{r}\text { Total } \\
\text { tested }\end{array}$ & \multicolumn{2}{c|}{$\begin{array}{c}\text { Morbillivirus positive } \\
\text { No. }\end{array}$} \\
\hline Atlantic spotted dolphin & 7 & 0 & 0 \\
Bottlenose dolphin & 128 & 12 & 9 \\
Clymene dolphin & 1 & 1 & 100 \\
Melon-headed whale & 2 & 0 & 0 \\
Rough-toothed dolphin & 1 & 0 & 0 \\
Spinner dolphin & 3 & 1 & 33 \\
Total & 142 & 14 & 10 \\
\hline
\end{tabular}

tra, a rough toothed dolphin Steno bredanensis, and spinner dolphins were tested in Florida (Table 2). Two PCR positive cetaceans stranded in 2010 (FL), 8 stranded in 2011 (FL, AL, MS, LA), 3 stranded in 2012 (AL, MS, LA), and one stranded in 2013 (MS) (Fig. 1, Table 3). Of the PCR-positive cetaceans, ages were not determined from the 2 non-bottlenose dolphins, but 9 of the 12 stranded bottlenose dolphins were $3 \mathrm{yr}$ or younger and measured $<205 \mathrm{~cm}$ in length (range 133-203 cm), while the remaining 3 bottlenose dolphins were subadults or adults measuring between 234 and $240 \mathrm{~cm}$ and aged as 10, 16, and $16 \mathrm{yr}$ old, respectively. Among the live, free-ranging bottlenose dolphins, from a total of 88 blowhole samples collected from 83 animals, only 1 adult female bottlenose dolphin, sampled in August 2011 in Barataria Bay, LA, tested positive for morbillivirus by PCR.

Sequencing of the morbillivirus P-gene fragment, amplified in the 15 morbillivirus-positive cetaceans (14 stranded; 1 free-ranging), yielded sequences most closely related to DMV. Additionally, the sequences from all 15 animals were 99 to $100 \%$

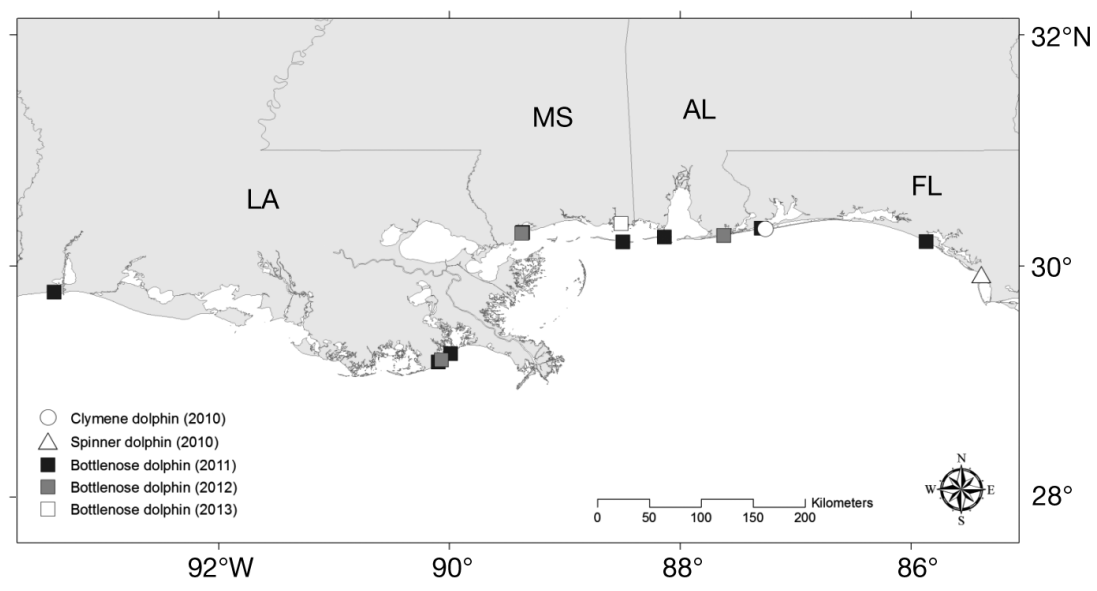

Fig. 1. Location of cetaceans stranded in the Gulf of Mexico in 2010-2013 that tested positive for morbillivirus by polymerase chain reaction (PCR) $(n=14)$ 
Table 3. States from which stranded cetaceans (from 2010-2014) were tested for morbillivirus by PCR and the years (n = number positive each year) and species in which morbillivirus was detected

\begin{tabular}{|lccccc|}
\hline State & $\begin{array}{c}\text { Total } \\
\text { tested }\end{array}$ & No. & $\%$ & Year (n) & $\begin{array}{c}\text { Morbillivirus positive } \\
\text { Species }\end{array}$ \\
\cline { 3 - 6 } & & & & & \\
Louisiana & 55 & 4 & 7 & $2011(3), 2012(1)$ & Bottlenose dolphin \\
Mississippi & 35 & 4 & 11 & $2011(2), 2012(1), 2013(1)$ & Bottlenose dolphin \\
Alabama & 18 & 2 & 11 & $2011(1), 2012(1)$ & Bottlenose dolphin \\
Florida & 34 & 4 & 12 & $2010(2), 2011(2)$ & Bottlenose dolphin, Clymene dolphin, Spinner dolphin \\
Total & 142 & 14 & 10 & & \\
\hline
\end{tabular}

similar to each other. Whole genome sequencing of morbillivirus from 3 stranded dolphins, ( 2 bottlenose dolphins: GenBank Accession nos. KU720624, KU720625; 1 spinner dolphin: GenBank Accession no. KU720623) showed the isolates from the animals in the GoM to be distinct from the bottlenose dolphin morbillivirus isolate (GenBank Accession no. KU720622) associated with the outbreak affecting cetaceans in the 2013-2015 mid-Atlantic UME (Fig. 2). Interestingly, phylogenetic analysis showed that the isolates from the GoM clustered together and were most similar to a DMV sequence amplified in tissue from a bottlenose dolphin that died off the Canary Islands, Spain (99.5\% nucleotide similarity, GenBank Accession no. KF695110).

\section{Histopathology}

A total of 136 fresh dead cetaceans that were tested for DMV by PCR had histopathologic evaluations. Histopathologic findings consistent with morbillivirus infection as previously defined were noted in $6.6 \%(9 / 136)$ of cases, and all of the cases with these lesions were positive for DMV by PCR, thus making these confirmed morbillivirus cases (Table 4). There were 5 positive PCR cases that did not show any histologic lesions and these were considered suspect cases. Of the 9 confirmed cases, 8 occurred in bottlenose dolphins and one was in the Clymene dolphin. None of the PCR negative cases had histologic lesions suggestive of morbillivirus infection. Lesions associated with viral infection were most common in animals stranding in 2010 and 2011. Only one of the 4 PCR positive dolphins that stranded during 2012-13 had histologic lesions attributable to infection.
The most common histopathologic lesion associated with morbilliviral infection was lymphoid depletion $(\mathrm{n}=7)$ within the spleen and or various lymph nodes, often with scattered syncytial cells within lymphoid tissues. Bronchointerstitial pneumonia was noted in 2 dolphins, one of which also had syncytial cells within the pulmonary lesions (Fig. 3A). Meningoencephalitis was observed in 3 infected dolphins, and 1 dolphin that stranded in 2013 with meningoencephalitis also had chronic degenerative lesions,

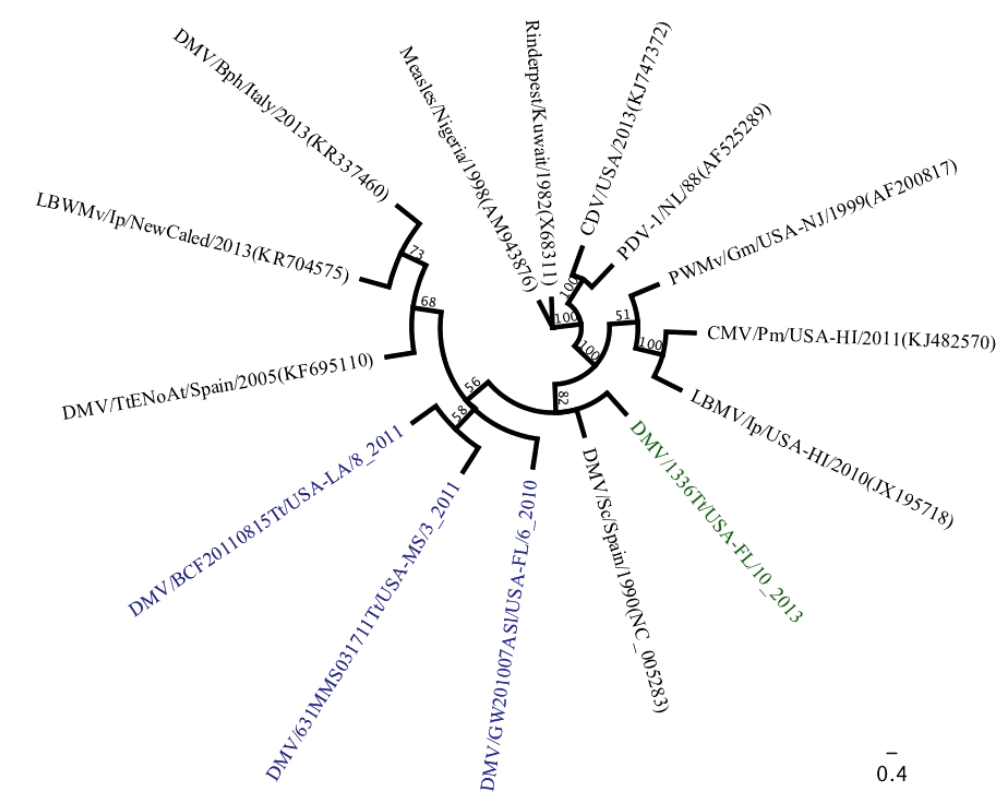

Fig. 2. Phylogenetic tree comparing a 389 bp fragment of the phosphoprotein gene (P-gene) of the dolphin morbillivirus isolates sequenced from 2 bottlenose dolphins and one spinner dolphin recovered dead in the Gulf of Mexico in 2010 and 2011 (blue; GenBank Accession nos. KU720623, KU720624 and KU720625) with corresponding phosphoprotein fragments from morbilliviruses (black), and an isolate from a bottlenose dolphin that died along the Atlantic coast of Florida during the 2013-2015 US mid-Atlantic unusual mortality event (green; GenBank Accession no. KU720622). Corresponding bootstrap values are shown at the bases of each branch. The scale bar indicates the number of nucleotide substitutions per site; measles (AM943876) was designated as the outgroup 
Table 4. Histopathologic lesions in stranded cetaceans recovered from the Gulf of Mexico in 2010-2013 that tested positive for morbillivirus by PCR. NA: not available

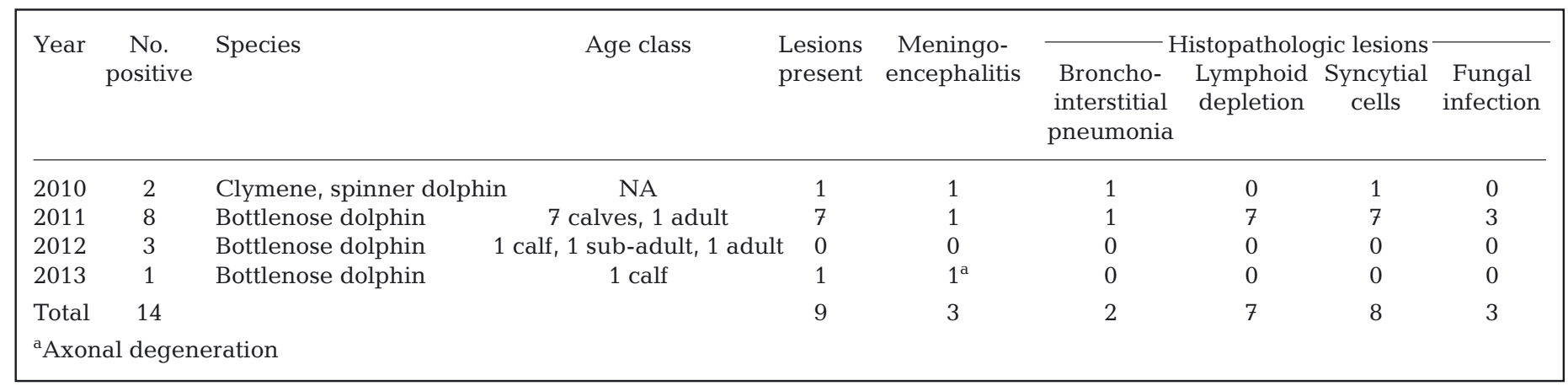

including marked regional axonal loss and demyelination (Fig. 3B). Eosinophilic intranuclear and/ or intracytoplasmic inclusions were rarely noted, and when present, were most commonly found within respiratory epithelium or syncytial cells. Secondary fungal infections were present in 3 of the 14 PCRpositive animals who also all had lymphoid depletion, suggesting impaired immune function. Of these 3 fungal infections, 1 animal had pneumonia and tracheitis associated with fungal organisms morphologically consistent with Aspergillus species infection. The other 2 animals had intralesional organisms morphologically consistent with a Zygomycete species with one case having fungal encephalitis, pneumonia, and tracheitis and the other having fungal nephritis.

\section{Serology}

Of live cetaceans tested by VN, 29\% (5/17) of stranded cetaceans and $23 \%$ (23/102) of free-ranging bottlenose dolphins had titers of $\geq 64$ for cetacean morbillivirus (Table 5). If equivocal titers were included (titers between 16 and 32) this percentage increased to a seropositivity of $47 \%(8 / 17)$ for the stranded cetaceans (Fig. 4). Of the stranded cetaceans tested, animals with positive titers $(\geq 64)$ were detected only in Mississippi, Alabama and Florida, with positive titers found in 3 bottlenose dolphins, one melon-headed whale and one rough-toothed dolphin (range 64 to $\geq 512$ ). Sero-positive cetaceans were detected in $2011(\mathrm{n}=1), 2012(\mathrm{n}=2)$ and 2013 $(\mathrm{n}=2)$. Equivocal titers (16 to 32 ) were found in 2
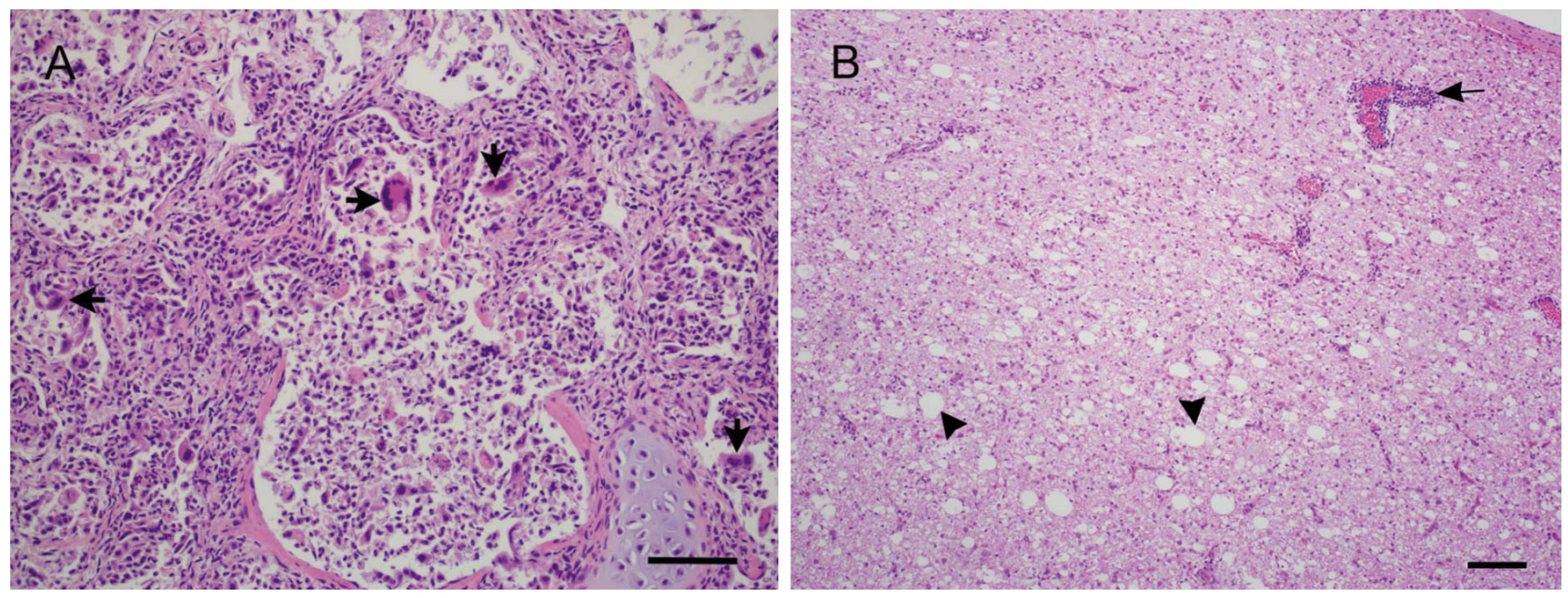

Fig. 3. Hematoxalin and eosin stained sections of tissues from bottlenose dolphins Tursiops truncatus with morbillivirus infection. (A) A section of lung with bronchointerstitial pneumonia. There is necrosis of bronchiolar epithelium, moderate inflammation within airways and alveolar septae, and numerous syncytial cells (arrows). Scale bar $=100 \mu \mathrm{m}$. (B) A section of midbrain from a dolphin with moderate lymphocytic encephalitis (arrow) and extensive axon loss (arrowheads) consistent with chronic morbillivirus infection. Scale bar $=100 \mu \mathrm{m}$ 
Table 5. Results of serum virus neutralization (VN) tests for morbillivirus on live cetaceans stranded on the coast of the Gulf of Mexico from Florida to Louisiana and free-ranging bottlenose dolphins captured in Barataria Bay, LA (BB) and Mississippi Sound, MS (MS) from 2010 to 2014. Titer values were assessed as seronegative $(\leq 8)$, equivocal $(16-32)$ or seropositive $(\geq 64)$. NA: not available

\begin{tabular}{|lccc|}
\hline \multirow{2}{*}{$\begin{array}{l}\text { Common name } \\
\text { Test result }\end{array}$} & Free-ranging & \multirow{2}{*}{ Stranded } \\
\hline Bottlenose dolphin & & & \\
$\quad$ Negative & 62 & 8 & 6 \\
$\quad \begin{array}{l}\text { Equivocal } \\
\text { Positive }\end{array}$ & 5 & 4 & 2 \\
$\quad \begin{array}{l}\text { Atlantic spotted dolphin } \\
\quad \text { Equivocal }\end{array}$ & 15 & 8 & 3 \\
$\begin{array}{l}\text { Melon-headed whale } \\
\quad \text { Positive }\end{array}$ & NA & NA & 1 \\
$\begin{array}{l}\text { Pilot whale } \\
\text { Negative }\end{array}$ & NA & 1 \\
$\begin{array}{l}\text { Pygmy sperm whale } \\
\quad \text { Negative }\end{array}$ & NA & NA & 1 \\
Rough-toothed dolphin & NA & NA & 2 \\
$\quad$ Positive & NA & NA & 1 \\
Total & 82 & 20 & 17 \\
\hline
\end{tabular}

bottlenose dolphins and one spinner dolphin, all from Florida, one each from 2011, 2012 and 2014. Of stranded animals that tested positive by $\mathrm{VN}$, only 2 bottlenose dolphins were also tested via PCR. These animals were positive in brain tissue with titers of $\geq 64$ and $\geq 512$, respectively, and the one animal with the higher titer had histopathologic lesions consistent with morbillivirus infection.

For the free-ranging bottlenose dolphins, animals with positive titers were found in both BB $(18 \%$; 15/82) and MS (40\%; 8/20) (Table 5, Fig. 4). If equivocal titers are included (16 to 32 ), this percentage increased to a seropositivity of $24 \%$ (20/82) for dolphins from BB and $60 \%(12 / 20)$ for dolphins from MS. For both locations, dolphin antibody titers ranged from 16 to $\geq 512$ and both $\mathrm{BB}$ and MS had animals with titers of $\geq 512$, BB in $2011(\mathrm{n}=4)$ and MS in $2013(\mathrm{n}=1)$. In $\mathrm{BB}, 16 \%(6 / 37)$ of subadults and $22 \%$ $(9 / 41)$ of adults were seropositive (data not shown). If equivocal titers are included, this percentage increased to $22 \%$ (8/37) for subadults and $27 \%(11 / 41)$ for adults; 1 positive animal could not be assigned to an age class. In MS $38 \%(5 / 13)$ of subadults and $60 \%$ $(3 / 5)$ of adults were seropositive. If equivocal titers are included, this percentage increased to $62 \%$ $(8 / 13)$ for subadults and $80 \%$ (4/5) for adults, while all calves (0/5) tested from both locations were seronegative. The one free-ranging adult female bottle-

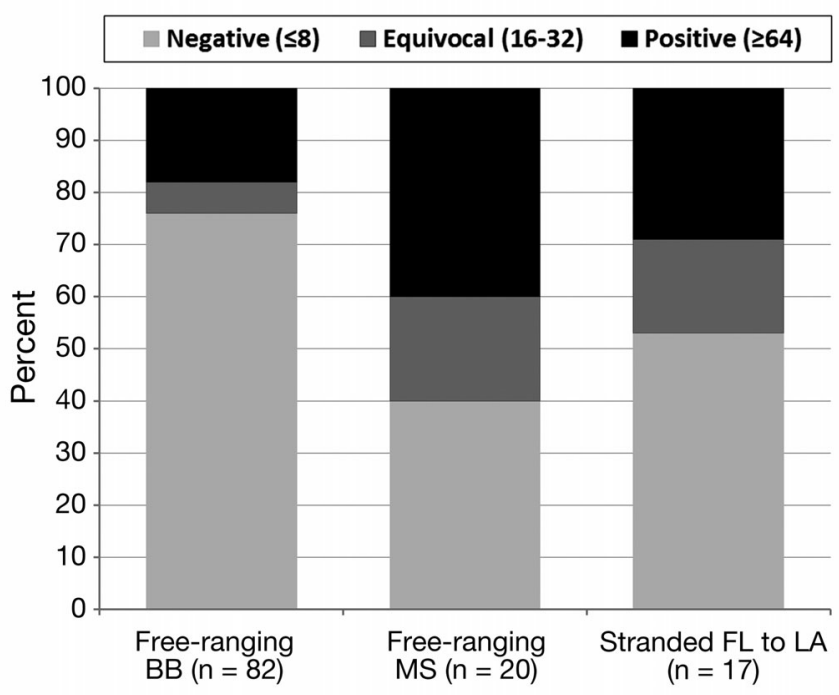

Fig. 4. Morbillivirus seroprevalence in cetaceans stranded on the coast of the Gulf of Mexico from Florida to Louisiana and live, free-ranging bottlenose dolphins captured in Barataria Bay, LA (BB) and Mississippi Sound, MS (MS), during 2010-2014. Titer values were assessed as seronegative $(\leq 8)$, equivocal $(16-32)$ or seropositive $(\geq 64)$

nose dolphin that had the PCR positive blowhole swab was an animal sampled in August 2011 from BB that had a high titer of $\geq 512$. This animal was still alive in July 2015 based upon photo-identification surveys.

\section{DISCUSSION}

Dolphin morbillivirus was detected by PCR in $9.9 \%$ of cetaceans stranding from February 2010 through July 2014, and 9 of these PCR positive cases had histopathologic lesions associated with viral infection. Histologic lesions were similar to those previously associated with morbillivirus infections in cetaceans (Lipscomb et al. 1994, 1996). In comparison, during the mid-Atlantic 1987-1988 bottlenose dolphin die-off, 97\% (35/36) of dolphins tested were positive for DMV using PCR (Schulman et al. 1997), and during the 1993-1994 GoM die-off, $61 \%(35 / 57)$ of dolphins had detectable DMV in tissues (Lipscomb et al. 1996). Further, $90 \%$ (186/207) of bottlenose dolphins tested by PCR from the 2013-2015 midAtlantic bottlenose dolphin UME were positive for

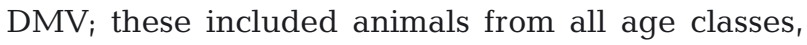
and many had histologic lesions consistent with DMV infection (Fauquier et al. 2014, Van Bressem et al. 2014). The relatively low prevalence of morbillivirus detected in tissues of stranded and live 
cetaceans during the current study compared to previously known DMV-associated die-offs, indicates that morbilliviral infection was not a primary cause of death in the northern GoM UME. Additionally, the 1993-1994 GoM morbillivirus has been found to be genetically distinct from the 1987-1988 mid-Atlantic morbillivirus (Taubenberger et al. 1996), and our partial and whole genome sequencing work confirms that the current GoM morbillivirus is distinct from the isolate found in cetaceans dying during the outbreak from 2013-2015 in the US mid-Atlantic.

The difference in seroprevalence between the BB and MS populations may be due to the physical properties of BB (i.e. closed bay) vs. MS (i.e. open embayment). For example, a more open home area could offer greater opportunity for interaction with potentially infected adjacent stocks of bottlenose dolphins and other small cetaceans compared to more isolated populations. A study that compared distinctive dolphin dorsal fins documented via photographic monitoring in St. Joseph Bay, Florida, and Mississippi Sound, found that at least a few of the photographed dolphins had extended ranges that included both of these areas (Balmer et al. in press). Additionally, a recent study found that frequency-dependent transmission predominantly regulated the 2013-2015 mid-Atlantic morbillivirus outbreak (Morris et al. 2015). Therefore, animals in the GoM with larger social networks could be at increased risk of morbillivirus exposure. Other small cetacean species (Atlantic spotted, Clymene, rough-toothed, spinner dolphins and a melon-headed whale) that stranded in the panhandle of Florida tested positive for DMV by PCR and/or VN, suggesting that offshore small cetacean species may be able to maintain the virus (Duignan et al. 1996). Therefore the Florida panhandle may be an important population mixing location, thereby increasing the potential for exposure of bottlenose dolphins to DMV in encounters with offshore species in this region.

The current study's detection of what appears to be increased morbillivirus infections in young GoM bottlenose dolphins $(<3 \mathrm{yr},<205 \mathrm{~cm})$ and seropositivity only in subadults and adults in BB and MS supports the theory that morbillivirus may be persisting in the GoM at non-epidemic levels; by contrast, large dieoffs impact all age classes, which was not observed in this study. Our VN findings (as defined) indicated 18 and $40 \%$ seroprevalence with up to 24 and $60 \%$ seroprevalence (if equivocal titers are included) for $\mathrm{BB}$ and MS respectively. Recent modeling indicates a herd immunity of $60 \%$ or more may be protective for GoM dolphin populations (Morris et al. 2015). There- fore, certain populations of GoM dolphins may have sufficiently high herd immunity and may be protected from severe outbreaks such as has been seen along the Atlantic coast. Following an outbreak, the prevalence of morbillivirus positive titers, as measured by serology, will decrease over time if there is no new exposure or limited exposure for the population (Duignan et al. 1996, Raga et al. 2008, Rowles et al. 2011). For example, during the outbreak of DMV in striped dolphins Stenella coeruleoalba from the Mediterranean Sea in the early 1990s, seropositivity decreased from $100 \%$ during the outbreak to $50 \%$ after 5 yr (Van Bressem et al. 2014). The survivors of infection during outbreaks are immunologically protected against DMV via antibodies, but through time, aging individuals are replaced with younger, immunologically naive animals, resulting in a loss of herd immunity and an opportunity for viral reintroduction and/or resurgence and another mortality event to occur. Our findings of relatively high herd immunity especially among subadult and adult MS free-ranging dolphins suggest that a cyclical morbillivirus exposure and infection process may be occurring at a low non-epidemic level in GoM cetacean populations with active infections predominantly found in youngeraged naive individuals. Specifically, the findings of PCR positives in young stranded animals, seropositive titers in the subadult and adult age classes of free-ranging bottlenose dolphins, and high titers in both BB and MS dolphins in 2011 and 2013 suggests there may have been a recent exposure event in the region that did not trigger an epidemic.

\section{CONCLUSIONS}

The current study demonstrated that morbillivirus infections occurred infrequently and were not a leading cause of death of cetaceans sampled between February 2010 and July 2014 or a cause of the GoM UME. In our investigation, only $6.6 \%(9 / 136)$ of confirmed morbillivirus infections were detected among fresh dead stranded cetaceans using a combination of histopathology and PCR. This number is substantially lower than that found during previous morbillivirus-associated dolphin die-offs in the northern GoM and elsewhere. Additionally, the partial and whole genome sequencing work confirmed that the current GoM morbillivirus is distinct from the isolate found in cetaceans dying during the 2013-2015 outbreak in the US mid-Atlantic. The majority of stranded bottlenose dolphins with active morbillivirus infections were $<3 \mathrm{yr}$ of age. Interestingly, this 
study's detection of what appears to be sporadic or episodic morbillivirus infections in younger GoM bottlenose dolphins supports the hypothesis that DMV is endemic in the region and is successfully persisting in some offshore small cetacean populations in the GoM. Periodic exposures in coastal bottlenose dolphin populations are most likely due to population and social dynamics of these dolphin stocks and their interactions with offshore small cetacean populations that may, collectively, be large enough to maintain the virus endemically.

Acknowledgements. This work was part of the Deepwater Horizon NRDA being conducted cooperatively among NOAA, other federal and state Trustees, and BP plc. The findings and conclusions in this paper are those of the authors and do not necessarily represent the view of NOAA or of any other natural resource Trustee for the BP/Deepwater Horizon NRDA. The authors thank members of the Working Group for Marine Mammal Unusual Mortality Events and the following individuals who have held critical roles in the ongoing northern GoM UME investigation: Jeff Adams, Micah Brodsky, Laura Dias, Laura Engleby, Lance Garrison, Michael Kinsel, Lauren Noble, Gina Rappucci, and Trevor Spradlin. This work could not have been conducted without the tireless efforts of the Southeast US Marine Mammal Stranding Network and the authors particularly acknowledge the staff and volunteers of the following agencies: Audubon Aquarium of the Americas, Dauphin Island Sea Lab, Emerald Coast Wildlife Refuge, GulfWorld Marine Park, Institute for Marine Mammal Studies, Louisiana Department of Wildlife and Fisheries, Louisiana Marine Mammal Stranding Network, McNeese State University, Mississippi Department of Marine Resources, Mote Marine Laboratory, National Park Service, National Marine Fisheries Service, St. Joseph Peninsula State Park, Southwest Florida Marine Mammal Stranding Network, Texas Marine Mammal Stranding Network, and Tyndall Air Force Base. We thank the staff at the Athens Veterinary Diagnostic Laboratory and the One Health Institute Laboratory for performing the laboratory analysis, especially Brett Smith, and also Dr. John Hammond for primers designed for primer walking to amplify the morbilliviral genome. This work was conducted under NMFS Permit 932-1905/MA-009526 and 112c and 109h NMFS Stranding Agreements.

\section{LITERATURE CITED}

Balmer B, Sinclair C, Speakman T, Quigley B and others (in press) Extended movements of common bottlenose dolphins (Tursiops truncatus) along the northern Gulf of Mexico's central coast. Gulf Mex Sci

Barrett T, Visser IK, Mamaev L, Goatley L, Van Bressem MF, Osterhaust AD (1993) Dolphin and porpoise morbilliviruses are genetically distinct from phocine distemper virus. Virology 193:1010-1012

Deepwater Horizon NRDA (Natural Resource Damage Assessment) Trustees (2016) Deepwater Horizon oil spill: final programmatic damage assessment and restoration plan (FDARP) and final programmatic environmental impact statement (PEIS). www.gulfspillrestoration.noaa. gov/restoration-planning/gulf-plan

* Di Guardo G, Marruchella G, Agrimi U, Kennedy S (2005) Morbillivirus infections in aquatic mammals: a brief overview. J Vet Med A 52:88-93

* Duignan PJ, House C, Odell DK, Wells RS and others (1996) Morbillivirus infection in bottlenose dolphins: evidence for recurrent epizootics in the western Atlantic and Gulf of Mexico. Mar Mamm Sci 12:499-515

Fauquier D, Goldstein T, Colegrove K, Rotstein D and others (2014) Update on the dolphin morbillivirus outbreak and the 2013-2014 US mid-Atlantic bottlenose dolphin (Tursiops truncatus) unusual mortality event (SC-65bE03). International Whaling Commission Scientific Committee Annual Meeting 2014, Environmental Concerns, SC-65b-E03; Resource ID 4973. https://archive.iwc.int/ pages/home.ph (accessed 14 Nov 2016)

Geraci JR, Lounsbury VJ (1993) Specimen and data collection. In: Marine mammals ashore: a field guide for strandings. Texas A\&M Sea Grant College Program, Galveston, TX, p 175-228

*Haffar A, Libeau G, Moussa A, Cecile M, Diallo A (1999) The matrix protein gene sequence analysis reveals close relationship between peste des petits ruminants virus (PPRV) and dolphin morbillivirus. Virus Res 64:69-75

* Hohn A, Scott MD, Wells RS, Sweeney JC, Irvine AB (1989) Growth layers in teeth from known-age free-ranging bottlenose dolphins. Mar Mamm Sci 5:315-342

Kennedy S (1998) Morbillivirus infections in marine mammals. J Comp Path 119: 201-225

Krafft A, Lichy JH, Lipscomb TP, Klaunberg BA, Kennedy S, Taubenberger JK (1995) Postmortem diagnosis of morbillivirus infection in bottlenose dolphins (Tursiops truncates) in the Atlantic and Gulf of Mexico epizootics by polymerase chain reaction-based assay. J Wildl Dis 31: 410-415

KLipscomb TP, Schulman FY, Moffett D, Kennedy S (1994) Morbilliviral disease in Atlantic bottlenose dolphins (Tursiops truncatus) from the 1987-1988 epizootic. J Wildl Dis 30:567-571

* Lipscomb TP, Kennedy S, Moffett D, Krafft A and others (1996) Morbillivirus epizootic in bottlenose dolphins of the Gulf of Mexico. J Vet Diagn Invest 8:283-290

Litz JA, Baran M, Bowen-Stevens S, Carmichael R and others (2014) Review of historical unusual mortality events (UMEs) in the Gulf of Mexico (1990-2009): providing context for the multi-year northern Gulf of Mexico cetacean UME declared in 2010. Dis Aquat Org 112: 161-175

*Morris SE, Zelner JA, Fauquier DA, Rowles TK, Rosel PE, Gulland F, Grenfell B (2015) Partially observed epidemics in wildlife host: modeling an outbreak of dolphin morbillivirus in the northwestern Atlantic, June 20132014. J R Soc Interface 12:20150676

NOAA Fisheries OPR (2016) Cetacean unusual mortality event in northern Gulf of Mexico (2010-2014). www.nmfs.noaa.gov/pr/health/mmume/cetacean_gulfof mexico.htm (accessed 1 June 2016).

* Raga JA, Banyard A, Domingo M, Corteyn M and others (2008) Dolphin morbillivirus epizootic resurgence, Mediterranean Sea. Emerg Infect Dis 14:471-473

Read AJ, Wells RS, Hohn AA, Scott MD (1993) Patterns of growth in wild bottlenose dolphins, Tursiops truncatus. J Zool (Lond) 231:107-123

Rima BK, Collin AM, Earle JA (2005) Completion of the sequence of a cetacean morbillivirus and comparative 
analysis of the complete genome sequences of four morbilliviruses. Virus Genes 30:113-119

Rossiter PB, Jessett DM, Taylor WP (1985) Microneutralization system for use with different strains of peste des petits ruminants and rinderpest virus. Trop Anim Health Prod 17:75-81

Rowles TK, VanDolah FM, Hohn AA (2001) Gross necropsy and specimen collection protocols. In: Dierauf LA, Gulland FMD (eds) CRC handbook of marine mammal medicine. CRC Press, Boca Raton, FL, p 449-469

Rowles TK, Schwacke LS, Wells RS, Saliki JT and others (2011) Evidence of susceptibility to morbillivirus infection in cetaceans from the United States. Mar Mamm Sci 27:1-19

Saliki JT, Lehenbauer TW (2001) Monoclonal antibodybased competitive enzyme linked immunosorbent assay for detection of morbillivirus antibody in marine mammal sera. J Clin Microbiol 39:1877-1881

Saliki JT, Cooper EJ, Gustavson JP (2002) Emerging morbillivirus infections of marine mammals: development of two diagnostic approaches. Ann N Y Acad Sci 969: 51-59

Schulman FY, Lipscomb TP, Moffett D, Krafft AE and others (1997) Histologic, immunohistochemical and polymerase chain reaction studies of bottlenose dolphins from the 1987-1988 United States Atlantic coast epizootic. Vet Pathol 34:288-295

Schwacke LH, Smith CR, Townsend FI, Wells RS and others (2014) Health of common bottlenose dolphins (Tursiops truncatus) in Barataria Bay, Louisiana, following the Deepwater Horizon oil spill. Environ Sci Technol 48:

Editorial responsibility: Michael Moore (Guest Editor), Woods Hole, Massachusetts, USA
93-103

* Sierra E, Saliki JT, Blas-Machado U, Arbelo M, Zucca D, Fernandez A (2014) Retrospective study of etiologic agents associated with nonsuppurative meningoencephalitis in stranded cetaceans in the Canary Islands. J Clin Microbiol 52: 2390-2397

Smith CR, Rowles TK, Hart LB, Townsend FI and others (2017) Slow recovery of Barataria Bay dolphin health following the Deepwater Horizon oil spill (2013-2014), with evidence of persistent lung disease and impaired stress response. Endang Species Res 33:127-142

* Taubenberger JK, Tsai M, Krafft AE, Lichy JH, Reid AH, Schulman FY, Lipscomb TP (1996) Two morbilliviruses implicated in bottlenose dolphin epizootics. Emerg Infect Dis 2:213-216

Taubenberger JK, Tsai MM, Atkin TJ, Fanning TG and others (2000) Molecular genetic evidence of a novel morbillivirus in a long-finned pilot whale (Globicephalus melas). Emerg Infect Dis 6:42-45

*Van Bressem MF, Raga JA, Di Guardo G, Jepson PD and others (2009) Emerging infectious diseases in cetaceans worldwide and the possible role of environmental stressors. Dis Aquat Org 86:143-157

*Van Bressem MF, Duignan PJ, Banyard A, Barbieri M and others (2014) Cetacean morbillivirus: current knowledge and future directions. Viruses 6:5145-5181

* Venn-Watson S, Colegrove KM, Litz J, Kinsel M and others (2015) Adrenal gland and lung lesions in Gulf of Mexico common bottlenose dolphins (Tursiops truncatus) found dead following the Deepwater Horizon oil spill. PLOS ONE 10:e0126538

Submitted: June 6, 2016; Accepted: September 13, 2016 Proofs received from author(s): November 15, 2016 